\begin{tabular}{r|l|l|l}
$\begin{array}{c}\text { Case Reports in } \\
\text { Oncology }\end{array}$ & $\begin{array}{l}\text { Case Rep Oncol 2011:4:155-161 } \\
\text { DOl: 10.1159/000327091 }\end{array}$ & $\begin{array}{l}\text { Published online: } \\
\text { March 22, 2011 }\end{array}$ & $\begin{array}{l}\text { @ 2011 S. Karger AG, Basel } \\
\text { ISSN 1662-6575 } \\
\text { www.karger.com/cro }\end{array}$ \\
\hline
\end{tabular}

\title{
Acute Respiratory Distress due to Thymoma in a Patient Treated with TK Inhibitor: A Case Report and Review of the Current Treatment Options
}

\section{$\begin{array}{llll}\text { P. Zarogoulidis } & \text { D. Matthaios } & \text { A. lordanidis } & \text { V. Zervas } \\ & \text { a }\end{array}$}

\section{A. Mitrakas $^{\mathrm{a}}$ G. Kouliatsis ${ }^{\mathrm{d}} \quad$ K. Zarogoulidis ${ }^{\mathrm{a}}$}

aPulmonary Department, 'G. Papanikolaou' Hospital, Aristotle University of Thessaloniki, Thessaloniki, Departments of ${ }^{b}$ Oncology and ${ }^{c}$ Radiology, and dIntensive Care Unit, Democritus University of Thrace, Thrace, Greece

\section{Key Words}

Thymic carcinoma - Thymoma - Targeted therapy · Fine needle aspiration · TK inhibitor

\begin{abstract}
Thymic malignancies are rare intrathoracic tumors that may be aggressive and difficult to treat in advanced stage. Surgery is the cornerstone of the management of thymomas: it is significant for the definite histopathological diagnosis and staging, and in most cases, it constitutes the first step of the treatment strategy. For patients with primary unresectable thymomas, the multimodal treatment schedule nowadays includes neoadjuvant chemotherapy, extensive surgery, adjuvant radiotherapy, and in some cases, adjuvant chemotherapy. A patient with a history of stage III COPD and an undiagnosed thoracic mass was admitted to the intensive care unit with acute respiratory distress. A radiologic evaluation by CT scan revealed a mass of $13 \mathrm{~cm}$ in diameter at the mediastinum. Fine needle aspiration was performed and revealed a thymoma. Due to poor performance status, the patient was not able to undergo surgery. He refused to be treated with neither chemotherapy nor radiotherapy, but due to EGFR overexpression, treatment with TK inhibitor was suggested. Fine needle aspiration biopsy is commonly used to identify metastasis to the mediastinum. However, it is less often employed as a primary diagnostic tool for tumors, particularly thymic neoplasms. The use of targeted therapies for the treatment of thymic malignancies has been described in the literature. Over the past years, significant efforts have been made to dissect the molecular pathways involved in the carcinogenesis of these tumors. Insights have been obtained following anecdotal clinical responses to targeted therapies, and large-scale genomic analyses have been conducted.
\end{abstract}




\section{Introduction}

Thymomas are the most common primary neoplasm of the anterior mediastinum but account for less than $1 \%$ of all adult malignancies [1]. Thymomas are usually slowgrowing tumors manifesting with local extension, which tend to spread along the serosal surfaces, i.e., along the pleura and pericardium, whereas extrathoracic metastases are uncommon [2]. The Masaoka staging system still remains a valuable and reproducible prognostic factor of thymoma. However, some proposals of revision of the staging system have been offered to identify significant differences in survival between each stage [3]. A large-scale study, which collected thymic epithelial tumors from multiple institutions in Japan, demonstrated that the Yamakawa and Masaoka TNM system classification (1991) is an excellent predictor of the prognosis of thymic epithelial tumors, including thymic carcinoma, in both overall and tumor-specific survival and that the $\mathrm{N}$ and/or $\mathrm{M}$ factors influence the prognosis more than the $\mathrm{T}$ factor [3]. For the subclassification of the $\mathrm{N}$ and/or $\mathrm{M}$ factors, large-scale studies, including resectable and unresectable tumors, are necessary.

Over the past 12 years, the Lung Disease Site Group (LDSG) has produced 25 evidence-based guidelines on various aspects of lung cancer [4]. Despite the advances in the treatment of thymoma that have occurred in the last two decades, there is little definite evidence to form guidelines of best clinical practice. Given the rare nature of these tumors and the multiple acceptable approaches to treatment, it was difficult for the LDSG to make definite recommendations. The current data do not adequately address certain controversial topics, which include: (1) the role of adjuvant treatment in stage II disease, (2) the choice, timing, and sequencing of combined modality therapy (i.e., surgery, radiotherapy, and chemotherapy) in stage III disease, (3) identifying for whom surgery is appropriate, and whether debulking surgery is appropriate in unresectable or disseminated disease as there is limited evidence to refute or support it, and (4) determining the best treatment approach to recurrent disease. At present, there is individual and institutional variation in the timing and sequencing of treatment and what extent of disease is regarded as being resectable [5].

\section{Case Presentation}

A 73-year-old Caucasian male, heavy smoker (120 pack-years), was admitted to the intensive care unit (ICU) with acute respiratory distress, SOFA score evaluation 14, and CURB-65 score 4 . The patient had a history of stage III COPD (FEV1, 35\%pred) (GOLD ERS/ATS) and an undiagnosed mediastinal mass of $5 \mathrm{~cm}$ in diameter, which had been first diagnosed by CT scan 3 years before. At that time, the patient had refused further investigation of the newly discovered undiagnosed mass. Upon admission, blood samples were collected and chest X-ray was conducted. His temperature was $39^{\circ} \mathrm{C}$, blood pressure: $90 / 70 \mathrm{~mm} \mathrm{Hg}$, heart rate: 60 beats/min, respiratory rate: 32 breaths/min and blood arterial gas was $\mathrm{PO}_{2}: 45 \mathrm{~mm} \mathrm{Hg}, \mathrm{PCO}_{2}: 80 \mathrm{~mm} \mathrm{Hg}$, pH: 6.50, and $\mathrm{HCO}_{3}: 45 \mathrm{mmol} / \mathrm{l}$ with $\mathrm{FiO}_{2}$ of $21 \%$. The laboratory findings were as follows: white blood count: $20,000 / \mu \mathrm{l}$, C-reactive protein: $22 \mathrm{mg} / \mathrm{dl}$, erythrocyte sedimentation rate: $25 \mathrm{~mm}$, procalcitonin: $2 \mathrm{ng} / \mathrm{ml}$, urea: $59 \mathrm{mg} / \mathrm{dl}$, creatinine: $0.8 \mathrm{mg} / \mathrm{dl}$, K: $4.1 \mathrm{mmol} / \mathrm{l}, \mathrm{Na}: 138 \mathrm{mmol} / \mathrm{l}$, SGOT: 23 U/l, SGPT: 39 U/l, LDH: 204 U/l, CPK: 15 U/l, ALP: 196 U/l, gGT: 103 U/l. Blood cultures were negative, but urine antigen for Streptococcus pneumoniae was positive. His X-ray presented a small pleural effusion on the left hemithorax, but the significant finding was the dilated upper mediastinum. The patient was intubated and admitted to the ICU. A CT scan of the thorax was performed to evaluate the dilated mediastinum. The undiagnosed mass had an increased size, measuring $13 \mathrm{~cm}$ in diameter (igg. 1). 
Initially, he was treated with a double antibiotic regimen consisting of ceftriaxone and ciprofloxacin for 7 days. After the 7-day regimen, he became afebrile, and we decided to perform a fine needle aspiration (FNA) biopsy (fig. 2), instead of choosing the usual surgical method $[3,6,7]$. The biopsy result was positive for EGFR expression by immunohistochemistry, and was consistent with the diagnosis of thymic carcinoma. According to the Masaoka staging system, the patient's stage was IVa.

The anesthesiologists and thoracic surgeons of our hospital decided that the patient was not a candidate for surgery: based on the stage III COPD with FEV1 (35\%pred) and an elevated postintubational $\mathrm{PCO}_{2}$ of $60 \mathrm{~mm} \mathrm{Hg}$ during daytime, he would not be able to wean off the mechanical ventilation after surgery. Although, multiple chemotherapy regimens with or without radiotherapy have been well established or administered experimentally, we decided to treat the patient with the TK inhibitor gefinitib $[5,8,9]$. The patient had a successful weaning from the mechanical ventilation, but he remained on noninvasive positive airway pressure ventilation, with a full face mask with continuous positive airway pressure (CPAP) $\left(17 \mathrm{~cm} \mathrm{H}_{2} \mathrm{O}\right.$ pressure/24 h daily). He was discharged with a portable CPAP device. During the next 4 months, he received gefinitib $(250 \mathrm{mg} /$ daily $)$ and his disease remained stable as judged by CT scan evaluation (fig. 3 ). We cannot be certain whether the tumor did not increase in size due to TK inhibitor administration or due to its slow growth, we can only speculate that the TK inhibitor administration had a positive effect because of the positive expression of the EGFR.

We decided that the patient should receive anticoagulation therapy with low-molecular weight heparin systematically in a daily prophylactic dose, since he would remain bedridden for a prolonged time. Unfortunately, the patient died at home on the fifth month after his hospital discharge, and the autopsy revealed massive pulmonary embolism.

\section{Discussion}

Thymomas usually present in the fourth and fifth decades of life [10, 11]. There is no clear sex predisposition. One third to one half of patients present with an asymptomatic anterior mediastinal mass on chest radiograph, one third present with local symptoms (e.g., cough, chest pain, superior vena cava syndrome, and/or dysphagia), and one third of cases are detected during the evaluation of myasthenia gravis. Distant metastases are distinctly uncommon at initial presentation of this tumor. However, when present, the most common metastatic site is the pleura, with involvement of the kidney, bone, and liver; brain metastases are infrequently seen.

The diagnostic work-up after CT scan usually includes surgical excision, which provides the precise histological and staging information necessary for the next therapeutic steps. The most common tumors that the clinician must include in the differential diagnosis of an anterior mediastinal tumor are lymphomas and germ cell tumors $[11,12]$.

FNA biopsy is commonly used to document metastasis to the mediastinum. It is less often used to make the primary diagnosis of tumors, particularly thymic neoplasms. This is due to problems of sampling error, rarity of thymic tumors, multiplicity of lesions in the mediastinum, and inexperience on the part of the cytopathologist. A common problem that clinical physicians and pathologists have to face when using FNA for biopsy is the small amount of material obtained. This disadvantage of the FNA technique has a serious impact on the result. The big 'small sample problem' will be encountered more and more nowadays, since less invasive procedures like FNA are more frequently preferred and, like in our case, they are successful in providing information regarding EGFR-expression status. The same problem is also encountered for lung cancer biopsies, where the obtained biopsy specimens are very small, and in most of the cases, the EGFRpositive mutation depends entirely on the 'right' area of the tumor where the biopsy is 


\begin{tabular}{r|l|l|l}
$\begin{array}{c}\text { Case Reports in } \\
\text { Oncology }\end{array}$ & $\begin{array}{l}\text { Case Rep Oncol 2011;4:155-161 } \\
\text { DOl: 10.1159/000327091 }\end{array}$ & $\begin{array}{l}\text { Published online: } \\
\text { March 22, 2011 }\end{array}$ & $\begin{array}{l}\text { O 2011 S. Karger AG, Basel } \\
\text { ISSN 1662-6575 } \\
\text { www.karger.com/cro }\end{array}$ \\
\hline
\end{tabular}

performed. Nevertheless, EGFR mutations are rare and a second biopsy should not be repeated unless the first is not positive for malignancy.

Targeted therapy with TK inhibitors (erlotinib-Tarceva and gefinitib-Iressa) is a wellestablished therapy for EGFR-positive mutation tumors. However, a question remains to be answered: Which of the two inhibitors is more efficient? This clinically based assumption remains to be discussed within larger studies. Furthermore, patients who present intense rush due to the TK inhibitor therapy seem to respond positively to this kind of treatment in comparison to patients who do not present intense rush. These patients show better results with smaller doses of TK inhibitors [13, 14]. Our patient did not present rushes, and unfortunately, although he was under low-molecular weight heparin, a massive pulmonary embolism occurred. This kind of event is expected to occur in patients with an extensive tumor burden [15].

Further studies with larger patient series evaluating whether this form of treatment is applicable to this type of cancer are needed. Small case studies or published case reports present conflicting data: some demonstrate stable disease or response to TK inhibitors, while others report disease progression $[14,15]$. In addition to EGFR, other parameters could be evaluated in histopathologic specimens such as RAF, VEGFR, PDGFR, c-KIT, FLT-3, HDACs and p38, and as a result, more treatment modalities could be explored and established as therapy [8].

In conclusion, we are convinced that this form of treatment could be applied in thymic tumors, as shown in published data. However, studies with larger patient series are yet to be completed. In addition, more parameters from systematic analyses of the genetic aberration profiles of these tumors remain to be explored to evaluate the efficacy of other treatment modalities.

\section{Ethical Approval}

Written informed consent was obtained from the patient upon discharge for publication of this case report and all accompanying images. A copy of the written consent is available for review by the Editor-in-Chief of this journal.

\section{Disclosure Statement}

The authors declare that they have no competing interests. 


\begin{tabular}{c|l|l|l}
$\begin{array}{c}\text { Case Reports in } \\
\text { Oncology }\end{array}$ & $\begin{array}{l}\text { Case Rep Oncol 2011;4:155-161 } \\
\text { DOl: 10.1159/000327091 }\end{array}$ & $\begin{array}{l}\text { Published online: } \\
\text { March 22, 2011 }\end{array}$ & $\begin{array}{l}\text { O 2011 S. Karger AG, Basel } \\
\text { ISSN 1662-6575 } \\
\text { www.karger.com/cro }\end{array}$ \\
\hline
\end{tabular}

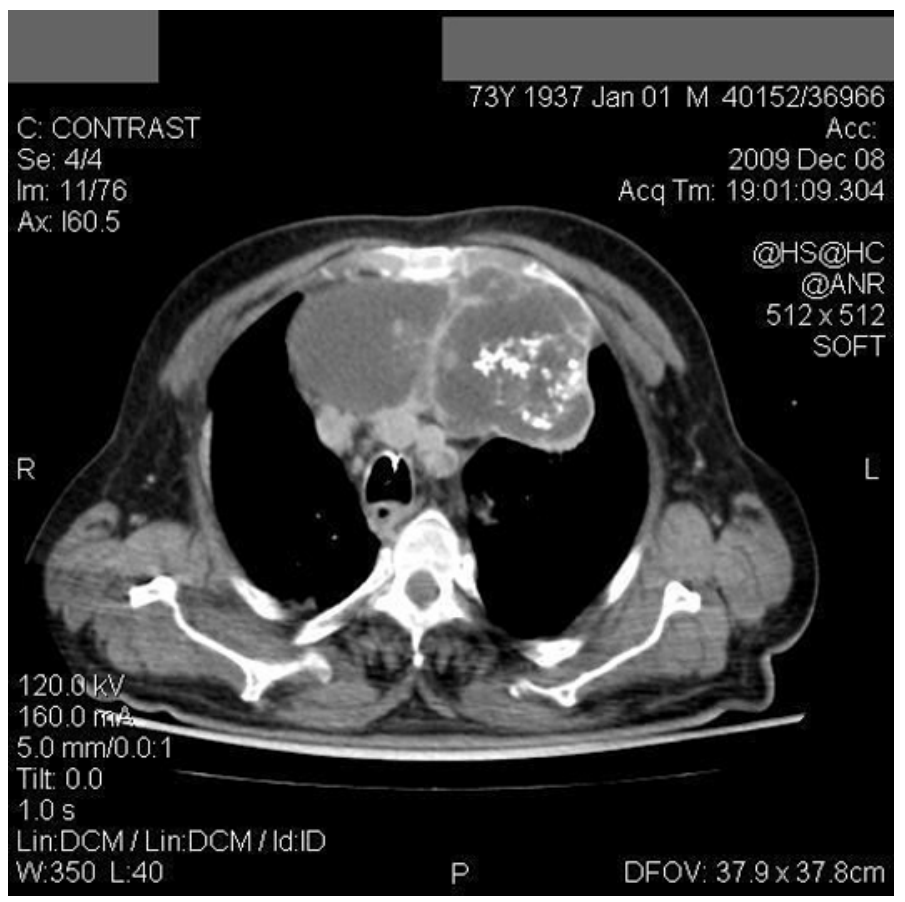

Fig. 1. CT scan of the mass located at the mediastinum, measuring $13 \times 7 \mathrm{~cm}$.

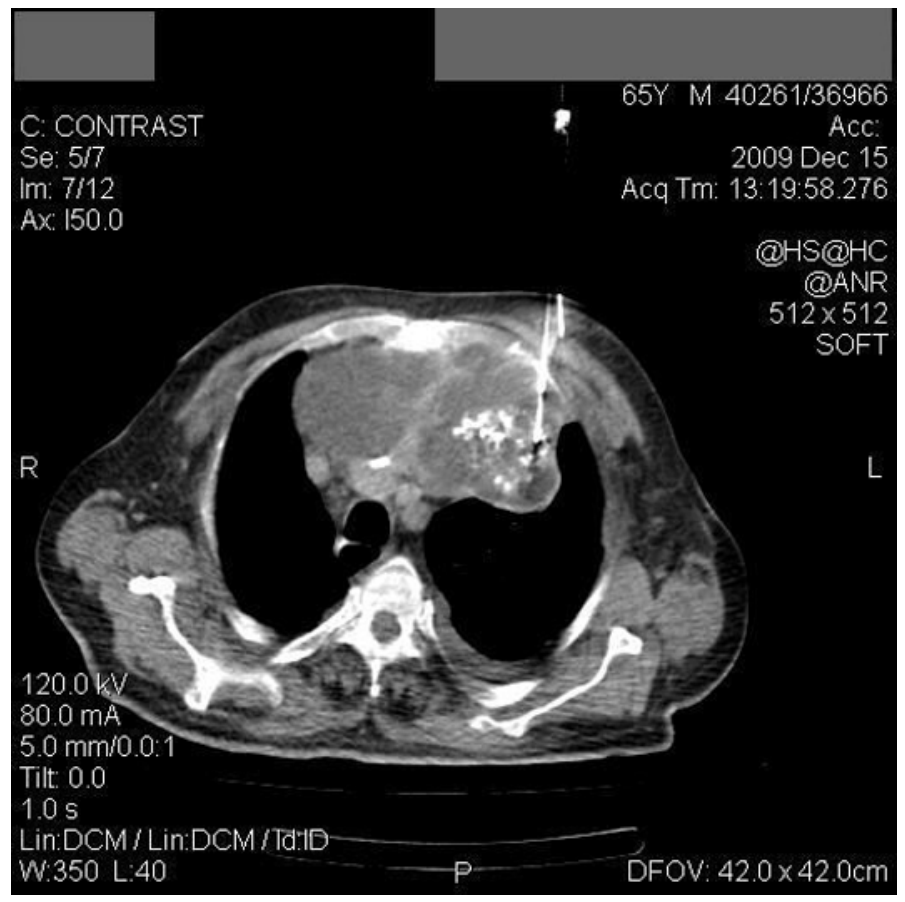

Fig. 2. CT-guided FNA of the mass. 


\begin{tabular}{c|l|l|l}
$\begin{array}{c}\text { Case Reports in } \\
\text { Oncology }\end{array}$ & $\begin{array}{l}\text { Case Rep Oncol 2011;4:155-161 } \\
\text { DOl: 10.1159/000327091 }\end{array}$ & $\begin{array}{l}\text { Published online: } \\
\text { March 22, 2011 }\end{array}$ & $\begin{array}{l}\text { O 2011 S. Karger AG, Basel } \\
\text { ISSN 1662-6575 } \\
\text { www.karger.com/cro }\end{array}$ \\
\hline
\end{tabular}

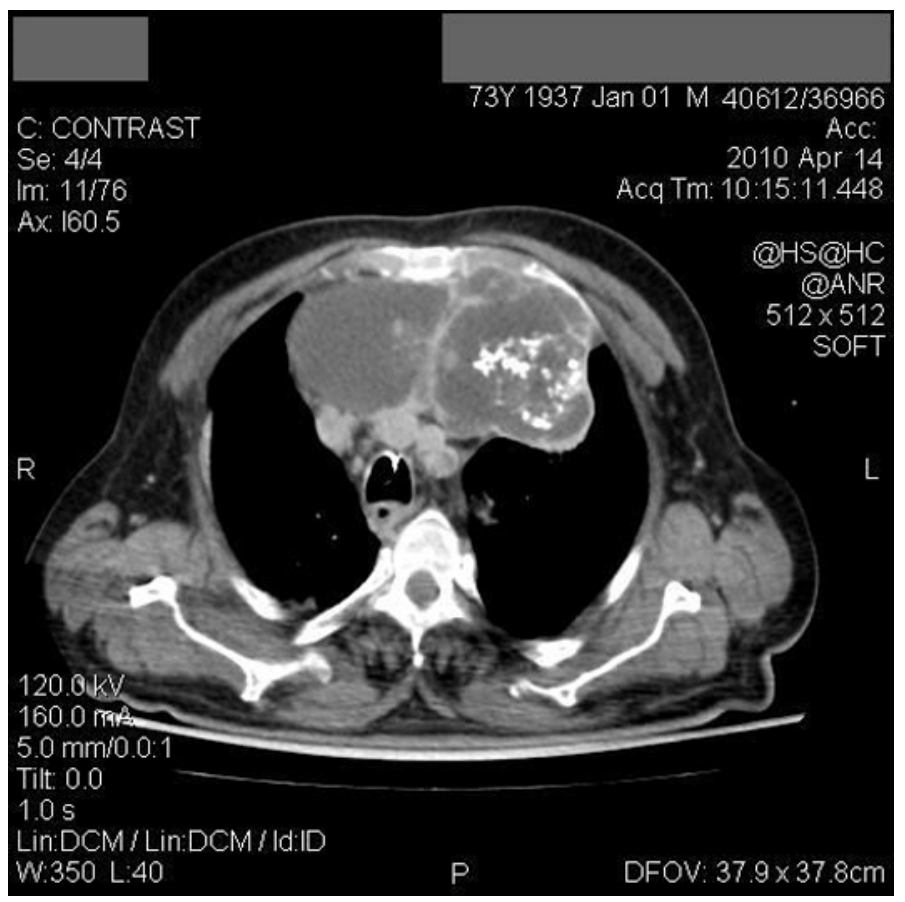

Fig. 3. CT scan reevaluation after 4 months. 


\section{References}

$\checkmark 1$ Duwe BV, Sterman DH, Musani AI: Tumors of the mediastinum. Chest 2005;128:2893-2909.

$\checkmark 2$ Regnard JF, Magdeleinat P, Dromer C, et al: Prognostic factors and long-term results after thymoma resection: a series of 307 patients. J Thorac Cardiovasc Surg 1996;112:376-384.

3 Masaoka A: Staging system of thymoma. J Thorac Oncol 2010;5:304-312.

-4 Regnard JF, Magdeleinat P, Dromer C, et al: Prognostic factors and long-term results after thymoma resection: a series of 307 patients. J Thorac Cardiovasc Surg 1996;112:376-384.

5 Conrad F, Andrea B, Gail D: The management of thymoma: a systematic review and practice guideline. J Thorac Oncol 2009;4:911-919.

6 Motoki Y, Hidefumi S, Tomoki Y, et al: Thymic carcinoma: 30 cases at a single institution. J Thorac Oncol 2008;3:265-269.

7 Zakowski M, Huang J, Bramlage M, et al: The role of fine needle aspiration cytology in the diagnosis and management of thymic neoplasia. J Thorac Oncol 2010;5:281-285.

$\checkmark 8$ Rajan A, Giaccone G: Targeted therapy for advanced thymic tumors. J Thorac Oncol 2010;5:361-364.

9 Christodoulou C, Murray S, Dahabreh J, et al: Response of malignant thymoma to erlotinib. Ann Oncol 2008;19:1361-1362.

10 Mullen B, Richardson JD: Primary anterior mediastinal tumors in children and adults. Ann Thorac Surg 1986;42:338-345.

-11 Wilkins EW, Grillo HC, Scannell G, Moncure AC, Mathisen DJ: Role of staging in prognosis and management of thymoma. Ann Thorac Surg 1991;51:888-892.

12 LeBlanc J, Wood DE: Diagnosis of mediastinal tumors; in Wood DE, Thomas CR Jr (eds): Mediastinal Tumors: Update 1995, Medical Radiology-Diagnostic Imaging and Radiation Oncology Volume. Heidelberg, Germany, Springer-Verlag, 1995, pp 1-10.

13 Wu YL, Zhong WZ, Li LY, et al: Epidermal growth factor receptor mutations and their correlation with gefitinib therapy in patients with non-small cell lung cancer: a meta-analysis based on updated individual patient data from six medical centers in mainland China. J Thorac Oncol 2007;2:430-439.

14 Henley JD, Koukoulis GK, Loehrer PJ: Epidermal growth factor receptor expression in invasive thymoma. J Cancer Res Clin Oncol 2002;103:167-170.

15 Geerts WH, Bergqvist D, Pineo GF, et al: Prevention of venous thromboembolism: American College of Chest Physicians evidence-based clinical practice guidelines (8th edition). Chest 2008;133(6 suppl):381-453. 